\title{
Educating The Next Generation Of Accounting Professionals
}

Gary Schader, Kean University, USA

Bert Wailoo, Kean University, USA

Stephen John, Kean University, USA

\begin{abstract}
Each year accounting graduates are recruited by the accounting firms that hope the new crop of employees will be technically prepared to serve the clients of the firm. They are looking for these recruits to have a mastery of the principles and concepts of the accounting courses they have taken. Proof of mastery is the student's ability to apply their accounting knowledge to solve their clients' accounting-related issues.
\end{abstract}

Many of these firms, if not all, devote substantial resources "on boarding" new employees and training them in the way the firm serves their clients. Those students who have mastered the accounting concepts in their undergraduate courses have a career building advantage over those who do not have mastery. A frequent topic of discussion at firm leadership meetings centers around how well prepared students are from the different universities. Inevitably the discussion turns to what are the most effective methods to teach accounting to the newest crop of potential accounting professionals. These same discussions take place at faculty meetings as well as at conferences for accounting educators across the country.

Keywords: Financial Activities; Cash Flows; Financial Transactions; Financial Reports; Income; Assets; Net Worth

\section{INTRODUCTION}

enior Professors Schader and Wailoo have very different perspectives on how to most effectively educate
the next generation of accounting professionals.

\section{Technological Advances Offering Innovative Classroom Instruction (Gary Schader)}

For time and the World do not stand still, change is the law of life and those who look only to the past and the present are certain to miss the future. John F. Kennedy

I have been teaching financial accounting and taxes at the college level for over 32 years. During this period, I personally witnessed a monumental change in the classroom relating to the morphing social, gender, and nationality-based student population, in addition to the explosion of material that needs to be taught. Reacting to these changes, I have searched for ways to modify my teaching techniques to make them more effective.

The volume of information that needs to be taught is exploding exponentially. The expanding GAAP pronouncements and interpretations, not to mention the transition to International Financial Reporting System (IFRS), provide the current accounting teacher with monumental challenges. Teaching the introductory course in Financial Accounting today is most challenging because we need to introduce students to significantly more and complicated accounting issues than in the past. Moreover, teaching the accounting major has resulted in the virtual impossibility of teaching the foundation of accounting topics in the traditional 15-week, two-semester course of Intermediate Accounting. Add to this challenge the need to teach students computerized accounting and tax preparation proficiency and research skills. 
As if these issues were not formidable enough, the frequency and volume of significant federal tax law changes over the past decade and GAAP, to a lesser degree, has significantly impacted the changing curriculum requiring annual, if not more frequent, modifications.

Given the above challenge to teach our accounting students ever-increasing and changing information, we must honestly admit that the college students of today, for the most part, are much less prepared to learn than their predecessors of 10 years ago. Today, I compete with distracters - social network updates, emails, texts, instant messages, and internet search programs, such as YouTube. All of these competing influences are delivered to the students in their classroom seats via their personal computers, iPads, or wireless telephones. These distractions are so much more invasive than those of the past decade when whispering between students was the most serious competitor to the lecturer.

As if the above situation were not daunting enough, current students desire (even demand) to be "entertained" during the lecture, as opposed to merely informed or taught; so no longer is the content of the lecture important, but the method of delivery is becoming significant.

For these reasons, the lecturer needs to find new methods and means of teaching. I am utilizing electronic techniques that focus and refocus the students' attention to the issues I am presenting, redirecting their constantly wandering attention back into the classroom. Also, it is important to engage the students to the subject being taught and encourage their active participation in classroom discussions.

For the last six years, I have used different technological tools to capture and direct students' attention and reasoning both inside and outside of the classroom. I will detail some of these aids and explain briefly what they are and how I utilize them.

\section{Electronic Homework Management}

In order to discuss overall concepts in the classroom in a "big picture" manner, in addition to not ignoring the level of detail that students need to properly record and adjust accounting transactions, I assign more homework exercises and problems than I did in my early teaching days in order to work on the students' accounting computational skills outside of the classroom. Electronic homework management programs have e-Texts built into the program, whereby the student can link to the related portion of the text to reference the author's discussion of the related concepts, explanations, and examples to the problem at hand. The programs also allow students multiple attempts at the same problem in order to provide them the opportunity to solve the problem in steps, each time refining their mastery of the material. The problems are also electronically graded to comply with the instructors' US constitutionally protected right against cruel and unusual punishment of having to grade all of the problems manually. Since they are electronically graded, the instructor can assign more problems to expose the students to many different concepts. The effort that the students put into their homework directly improves their interest and mastery of the material presented in lecture, and their grade on the homework can be incorporated into their final grade, reinforcing their desire to do well on the homework.

Computer Response System, "Clicker”

Electronic homework management programs should enable students to come to class better prepared than otherwise. Yet, it is important to focus and maintain their attention throughout the lecture, given the multitude of distractions that I discussed earlier. Also, there is increased attention to assess in-class learning. The classroom response system starts to address these issues.

I developed slides that I project on the front screen throughout my lecture. The students initially respond by answering a multiple-choice question. I then lecture on the material presented in the slide, leaving the slide open which allows the students to change their answer(s) if they change their minds based on the content of my lecture. As the student understands the material, the correct answer should become clear. When they change their answer, their individual number displayed on the bottom of the slide flashes from blue, to yellow, and then back to blue. It is this feedback that provides me with knowledge that the students are listening to the lecture and changing their initial 
answer if it appears wrong. The only problem with the eInstruction system I use is that I do not know which answer(s) the students have changed. If I could capture this information, I would be able to quantify the in-class assessment of the actual learning of each student. If a student changed their answer from an incorrect answer to a correct answer, I can quantify that I imparted knowledge to that student. If a student changes their answer from a correct answer to an incorrect answer, I need to consider what part of my lecture confused the student and make modifications to respond to that problem.

This type of information is valuable to determine how well prepared the students were when they walked into the classroom and how well the lecturer clarified and taught the material during his or her lecture. Also, when the lecturer completes a certain point and closes the slide, the results are presented in summary; i.e., how many students answered A, B, C, etc. It doesn't detail who answers what, but each individual student knows their own answer. In this way, each student can see how he or she is doing in comparison to the other students. If they are one of a few students that answered the question wrong, they would realize that they are falling behind, which may motivate them to seek outside help to catch up. For the instructor, he or she can evaluate how well the class understands the concept being presented, and if the feedback implies that a significant portion of the class still does not understand the issue, the lecturer can immediately modify the lecture to continue on that topic.

Furthermore, by use of programmed slides, I can rechannel the class' attention back to my lecture by making them read and respond to a new slide every two to five minutes. As some students start to become distracted, I present a new slide and those students' attention is refocused and most of the class is brought to a common point. I have 12 semesters of two to five classes per semester of student surveys regarding their evaluation of their experience using the clicker. More than $75 \%$ of my students stated that the way I utilize the clicker maintained their focus in class more than in other classes. Also, by having to answer a question by pushing a button, this form of active learning, as opposed to passive learning by merely listening to a lecture and/or reading Power Point slides, appears to reinforce the learning process. Several studies have documented that active learning stimulates specific parts of the brain, which seems to enhance the learning experience.

Many students are shy based on their individual culture or due to their innate personality. It is very difficult for a lecturer to gain insight into how much of the subject that these types of student understand from classroom lectures; and if their final grade is derived solely from written exams, there remains a doubt that you are assigning that student a truly fair appraisal of their overall understanding of the subject. More than $75 \%$ of the students responding to my surveys indicated that they like being able to answer questions using the clicker so that they are not "spotlighted" in the class. However, using the clicker, I can quantify objective evidence as to how much they understood throughout the semester and I can use this 15-week semester feedback as evidence to favorably affect their final grade. Some students are poor test takers and the more non-test information I have about a student, the better I can assign a grade regarding how much a student knows about the subject rather than merely rely on the results of two or three written exams. Also, if a student was ill, upset, fatigued, or even stressed at the time they were taking a timed exam, their positive performance could have been severely negatively impacted. Thus, we can't be content that the results of written exams produce results that are a fair evaluation of that students' knowledge of the material tested.

\section{Summary}

Today, by using electronic homework management software and the clicker in the classroom, I can evaluate how well the student had prepared outside of the classroom before the lecture and how well they followed the material presented in the classroom. These electronic aids have provided me with new techniques to "get into the heads" of my students and monitor their actual learning. Given the multitude of distractions, along with the fact that students today do not prepare for lectures by reading the text and completing the homework before attending the lecture on that material, the teacher has to utilize these technological tools to "motivate" students to do what is necessary for them to learn the material in an effective way. Students entering class without having read the assigned chapter(s) or having worked the assigned end-of-chapter material, in combination with the material becoming more and more complicated and expansive, work in tandem to make it harder for our students to succeed. We teachers need to utilize new and unique instruction methods to stimulate and motivate our students to master the challenging content required of today's accounting and tax students. 
Furthermore, the practicing CPAs of today expect that our graduating students know how to use the technological aids that are routinely utilized in the industry. Accordingly, I have incorporated computerized income tax preparation programs as an integral part of my federal income tax courses. Learning the tax law is very important, but knowing how to present that information on the correct forms is also critical. By having the students learn how to enter data into a computerized income tax preparation program, they begin to appreciate what information needs to be entered and how to enter that information into a computerized program. They can then utilize the software program as a resource to review the propriety of the information that they inputted and to keep up with future changes in tax laws.

I also teach students how to use computerized accounting write-up software. Today, our students must be computer literate in processing accounting information. We need to teach them how to create a relevant and functional chart of accounts and how to process information leading to the preparation of the financial statements. The days of the manual multi-column worksheet have all but disappeared. Students need to understand the "adjusting phase" of the accounting cycle and how to make the necessary adjustments to the account balances in the system leading to finalizing the records before preparing financial statements. They should not be expected to accomplish these adjusting entries manually.

Regarding the preparation of income tax returns, outside accounting firms, especially the smaller sized practices, depend upon these programs to streamline their data capture process and speed up their preparation of financial statements and income tax returns. We must provide our students with this technical skill so that they can hit the ground running and become a sought after resource by these accounting firms.

\section{An Approach To Teaching Principles Of Financial Accounting 101 (Bert Wailoo)}

At the end of this course, the student must be able to prepare an Income Statement, a Balance Sheet, a Statement of Stockholders' Equity, and a Statement of Cash Flows. The student must also be able to analyze key categories of the balance sheet, such as cash, accounts and notes receivable, inventories, and long-term assets. In addition, the student must understand who the external users of these financial statements are, what format is used to provide this information to them, and, to a lesser extent, what financial measurements users use to evaluate the company's results of operations and financial position.

Accounting is not a spectator sport. One has to be in the game and must perform every activity. The Promised Land is looking at financial statements prepared by your own hands from information that you have analyzed, journalized, recorded in your books, prepared a trial balance, and completed a worksheet. Follow these steps and see if can prepare an income statement and a balance sheet for yourself or anyone else in less than an hour. The statement of cash flows will take less than that.

Now suppose you have started a small business, put some cash in it, rented office space and signed a 12month lease with a lease deposit, hired two part-time college students, purchased three computers, received cash from your customers for services, gave credit to others to be paid in 30 days, paid wages to your employees, bought supplies for cash and on credit, purchased furniture on credit, paid yourself a salary, etc. These are the normal financial activities that occur in any business. There are other contractual and operational activities, which, of course have financial implications. For example a lease agreement is a contractual activity while a lease payment is a financial one.

The cash transactions will, of course, be in your checkbook and the non-cash ones by support documentation. At the end of the first month, you want to take a look at your financial position, the results of your month's operations, and 'where did your money go?' (as they say in street jargon); that is, you want to see a balance sheet, an income statement, and a statement of cash flows.

So, here we go. I will set two codes up - B for balance sheet and I for income statement. The statement of cash flows will come from information taken from B and I. 
First Rule

Every financial transaction has at least two effects - on two types of B's perhaps; on two types of I's perhaps; or on a B or an I.

Second Rule

The B shows what we own (assets), what we owe (liabilities), and what we're worth (equity). The I shows what we earned from our services or sales and what it cost us to provide these services or sales. The difference between the two is our income.

So, let's put some numbers on the transactions described above to start a small business and prepare a B and an I. Table 1 summarizes the transactions needed to start a small business and the effect these transactions have on the financial statements.

Table 1: Transactions Summary

\begin{tabular}{|c|c|}
\hline Transactions & Effect on Financial Statements \\
\hline (a). Invested $\$ 50,000$ in the business--- 2B's & Cash 50,000(B), Equity $\$ 50,000(B)$ \\
\hline (b). Signed a lease- contractual & No effect \\
\hline (c). Paid one month's rent $\$ 400---1 \mathrm{I}$ and 1B & Rent expense $\$ 400(\mathrm{I})$, Cash $\$ 400$ (B) \\
\hline (d). Hired part- time students- contractual & No effect \\
\hline (e). Paid wages to part-time students $\$ 500---1 \mathrm{I}$ and $1 \mathrm{~B}$ & Wages expense $\$ 500(\mathrm{I})$ and Cash $\$ 500(\mathrm{~B})$ \\
\hline (f). Purchased 3 computers $\$ 6000$ for cash---2B's & Equipment \$6000(B), Cash \$6000(B) \\
\hline $\begin{array}{l}\text { (g). Provided services of } \$ 5000 \text {. Received cash } \$ 3000 \text { and the } \\
\text { balance owed to you ---- 2B's and 1I }\end{array}$ & $\begin{array}{l}\text { Cash } \$ 3000(B), \text { Accounts Receivable } \$ 2000(B), \text { Revenue } \\
\$ 5000(\mathrm{I})\end{array}$ \\
\hline $\begin{array}{l}\text { (h). Other expenses. Paid cash -Insurance and utilities \$300 1I } \\
\text { and 1B }\end{array}$ & Other expenses (I) \$300. Cash \$300 (B) \\
\hline (i). Purchased supplies $\$ 200$ on credit 1I and 1B & Supplies expense (I) \$200, Accounts Payable (B) \$200 \\
\hline
\end{tabular}

\section{(A) Income Statement}

Revenue

$\$ 5000$

Expenses:

Rent expense $\$ 400$

Wages Expense $\quad 500$

Supplies expense 200

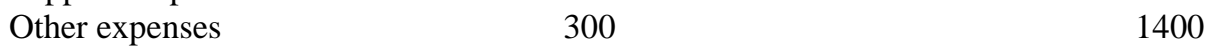

Income $\$ 3600$

$*_{\text {Cash }}+50,000-\$ 400-\$ 500-\$ 6000+\$ 3000-\$ 300=\$ 45,800$

\section{(B) Balance Sheet}

\section{$\underline{\text { Assets }}$ \\ Cash}

Accounts Receivable

Equipment

Total assets

$$
\begin{array}{r}
\$ 45,800 \\
2,000 \\
6,000
\end{array}
$$

$\$ 53,800$

\section{$\underline{\text { Liabilities }}$}

Accounts Payable

Equity

Capita $\$ 50,000$

Income

3,600

Total Liab \& Equity
$\$ 200$

53,600

$\$ 53,800$ 
The statement of cash flow analyzes the cash account from information provided by the balance sheet and income statement. In this case, the business began with $\$ 50,000$ dollars and now has $\$ 45,800$ - a reduction of $\$ 4,200$. Where did the money go?

From the list of transactions above, $\$ 3,000$ was received for services; i.e. operating activities, $\$ 1,200$ for cash expenses (operating costs), $\$ 6,000$ for the purchase of computers (investing activity), which reduced cash by $\$ 4,200$.

\section{Statement of Cash Flows}

Cash received from customers

Cash paid to vendors

Net cash inflows from operating activities

Cash paid for purchase of computers

Net cash outflows from investing activities

Change in cash

Beginning cash

Ending cash

$\$ 45,800$

Using the transactions from Table 1, complete the following steps:

Step1: Transfer all revenue items to the income statement - Item (g).

Step2: Transfer all expense items to the income statement - (c, e, h \& i).

Step 3: Subtract step 2 from step 1. The amount obtained is your net income (see below for completed income statement).

Step 4: Transfer all asset items to balance sheet - (a, c, e, f \& g).

Step 5: Transfer all liability items to balance sheet - (i).

Step 6: Subtract step 4 from step 5. Add amount to net income. Your Balance Sheet is complete and in balance.

\section{Close}

Now it's your turn. You are a corporation. Collect your financial information. Remember, revenues are what you earn, expenses are what you incur, and income is the difference between the two. Assets are what you own, liabilities are what you owe, and equity is what you are worth. Follow the steps above. Now you've got it. Are you a hot accountant or what?

Recently, in a junior year cost accounting class, I inquired if they had worked with accounting paper and pencil to solve problems in their other courses. Not one out of ten students had seen a thirteen column worksheet. I introduced them to it, adapting the above example to a cost accounting problem they would encounter in a work situation or in sitting for the CPA exam. This is the way to educate our next wave of accounting professionals. They will be better for it, as well as the clients they serve and firms or companies in which they work.

\section{CONCLUSION}

As you can see, Professors Schader and Wailoo present compelling arguments for their preferred educational techniques. You most likely would find the same polar opposite perspectives in the firms that hire their graduates. I returned to teaching accounting after two decades in the Human Resource Strategy and Executive Education arena. My preferred educational method is to utilize Professor Wailoo's techniques up to the point of 
producing financial statements and then switch to technology-based education - "the clicker and/or textbook publisher's websites for homework management.

As with any complex topic, educating the next generation of accounting professionals defies a "cookie cutter approach"; i.e., one size fitting all students. Each student is unique in the way they learn. The challenge for all faculty is to vary the teaching techniques utilized to reach all students. Our primary goal as accounting educators is to prepare our students to understand and apply the principles and concepts of accounting as they build their careers.

\section{AUTHOR INFORMATION}

Gary Schader, CPA. MBA, has been teaching at the college and graduate levels for over 35 years and has served as Chair of the Department of Accounting at Kean University. He has a BA in Economics from Rutgers College and an MBA with dual concentrations in Financial Accounting and Health Care Administration from the Wharton Graduate School of Finance. His business background is diverse, ranging from practical public accounting/auditing and consulting experience with international experience, to practical business experience in financial reporting, taxes and internal consulting with international experience, to practical experience in organizing and running a local CPA accounting practice (from which he has retired) which dealt with issues of importance to small and medium-sized businesses in both the domestic and international areas.

Professor Wailoo is a Senior Professor in the Department of Accounting and Finance at Kean University. His current research/writing is on 1:1 Financial Concepts and Financial Reporting Standard entitled - 168 Financial Accounting Standards Made Easy and 2. Business Valuation and the Role of Forensic Accountants in Divorce Settlements. Prior to joining Kean, Professor Wailoo worked in both the private and public sectors. He held Finance and Managerial positions at International Paper Company, Becton Dickinson, the Newark School of the Arts, and the Union Township Action Organization. He holds an MBA, CPA, CMA, CFF, and CGMA Certification. E-mail: Kean203@AOL.com

Stephen John, EdD, MBA, CPA, is currently the Executive Director of the School of Accountancy/Finance for Kean University. His current research is Educating the Next Generation of Business Leaders: Accounting for Sustainability (a new course created for undergraduates, graduate students, and executive education), Building Successful Change Alliances between the CFO, CHRO, and local communities, and Sustainable Identity as a Competitive Advantage. Prior to his joining Kean, he was a senior Human Resource executive responsible for executive education/organizational effectiveness for sanofi aventis, Brown Brothers Harriman, Andersen, UBS, Marsh and Coopers \& Lybrand. He has a doctorate in Adult Learning and Leadership from Columbia University, has an MBA/CPA, and has a BS in Physics with a specialty in using Cyclotrons. E-mail: s1john@kean.edu. Corresponding author.

\section{REFERENCES}

1. John, S. (2009). Strategic Learning and leading Change: How Global Organizations are Reinventing HR. Elsevier Butterworth Heinemann. Oxford, UK.

2. Bladden, A. and John, S. (2010) Strategic Advantage: Become a Change Agent for Learning. Leadership Excellence: Magazine of Leadership Development, Managerial Effectiveness and Organizational Productivity, (Warren Bennis, Editor) Volume 27 No. 11.

3. Paulson, Donald R \& Faust, Jennifer L, internet reference (no date included), "Active Learning for the College Classroom," California State University, Chemistry Department, http://www.calstatela.edu/dept/chem/chem2/active/.

4. Carroll, Ken, Linear and Non-Linear Learning, December 13, 2009, internet article, http://kencarroll.com/2007/12/13/linear-and-non-linear-learning/.

5. Bonwell, Charles C. and Elison, James A., "Active learning: Creating Excitement in the Classroom," (ASHE-ERIC Higher Education Report 1, 1991) Washington D.C., George Washington University Clearninghouse on Higher Education, http://www.ntif.com/htm/lib/bib/91-9dig.htm.

6. "Using Active Learning in the Classroom," Instruction at FSU Handbook, 2011, pages 75 - 102, ctl.fsu.edu/explore/onlineresources/docs/Chptr8.pdf. 
7. Gullette , Margaret Morganroth Editor (1982). “The Art and Craft of Teaching”. Harvard-Danforth Center for Teaching and Learning, Boston, MA.

8. Beasley, Mark S, Buckles, Frank A. (2002). "How Accounting Helped Make The Difference". Prentice Hall, Englewood Cliffs, NJ.

9. Spiceland, J. David, Thomas, Wayne, \& Hermann, Don, (2011)."Financial Accounting” Second Edition, McGraw- Hill Irwin, NYC, NY. 